\title{
The Importance and Perspectives of Sovereign Wealth Funds in the Globalised Economy
}

\author{
Jan Černohorský ${ }^{1, *}$, Kateřina Tesnerová ${ }^{1}$ \\ ${ }^{1}$ University of Pardubice, Faculty of Economics and Administration, Institute of Economic Sciences, \\ Studentská 95, 53210 Pardubice, the Czech Republic
}

\begin{abstract}
.
Research background: The ever-increasing degree of globalization is reflected, among other things, in the establishment of relatively new institutional investors - sovereign wealth funds. Until the financial crisis in 2008, these funds were considered by many developed countries to be a potential threat to national security. However, this changed when they invested large sums in bankrupt companies and banks during the crisis. However, fears of their influence remain.

Purpose of the article: The paper aims to assess the importance and perspectives of sovereign wealth funds in the world economy. In this paper, we start with the definition of sovereign wealth funds and distinguish them from other state asset managers. We also focus on assessing their importance within the global investor portfolio and their impact on global economic development.

Methods: We used an analysis of available financial and economic data related to their activities and comparison with selected asset managers.

Findings \& Value added: We discuss their specific investment strategies and their transparency, which affect their credibility. Within the evaluation, the positive benefits outweigh the risks of sovereign wealth funds. However, we should always assess in the context of a specific sovereign wealth fund. The importance of sovereign wealth funds and their impact will continue to grow, even though their relative share of the global financial market is not very high. Thanks to their long-term investments, they contribute to greater stability of the financial markets of the given countries.
\end{abstract}

Keywords: Sovereign Wealth Funds; Financial Markets; Investment; Foreign Exchange Reserves

JEL Classification: $F 62 ; F 65$; G23

\footnotetext{
*Corresponding author: jan.cernohorsky@upce.cz
} 


\section{Introduction}

Sovereign wealth funds (SWFs) are a relatively new financial institution in comparison to traditional financial institutions, such as banks, insurance companies, monetary and mutual funds, and other similar institutions. Sovereign wealth funds operate on financial markets in the same way as classical investment companies, i.e., they invest in stocks, real estate, bonds, commodities, or other financial instruments. Interest in them has increased greatly; primarily on account of marked growth in the value of the assets they manage, caused by a sharp increase in the price of oil on the world markets and a change in their investment strategy in favor of achieving more significant shares in globally important companies.

Sovereign wealth funds' increasing influence also generates a number of questions and concerns, because it is common for certain sovereign wealth funds to have insufficient regulation and transparency. Up until the financial crisis in 2008, many developed countries considered sovereign wealth funds to be potential threats to national security. However, this changed when they invested a significant amount into failing companies and banks during the crisis. Similarly, we now know about the first investments by sovereign wealth funds relating to the coronavirus crisis. Still, concerns about their influence continue to remain.

During the past decade, sovereign wealth funds have been acting as an important new force in global finance. They are dynamic institutional investors emerging in both developed and developing countries. Over the past two decades, a commodity price boom, a global imbalance between savings and investment in large countries, and massive accumulation of foreign reserve assets has led to sovereign wealth funds becoming significant players on the international financial markets.

There is no generally acceptable, universal definition of the term sovereign wealth fund (SWF) that can describe exactly what they are. A number of definitions have been put forth; we have presented the most well-known of these in the following section.

Regarding the above, it is the goal of this paper to assess the importance and perspectives of sovereign wealth funds in the world economy.

\section{Theoretical Background}

The Sovereign Wealth Fund Institute [1] defines a sovereign wealth fund as a "state-owned investment fund or entity that is commonly established from: (i) balance of payments surpluses, (ii) official foreign currency operations, (iii) the proceeds of privatizations, (iv) governmental transfer payments, (v) fiscal surpluses (vi) and/or receipts resulting from resource exports." The International Monetary Fund defines SWFs as government investment funds established for various macroeconomic purposes. Usually, they are financed by the transfer of foreign exchange reserves, which are then invested abroad over the long term [2]. Connelly et al. [3] define SWFs simply as "investment vehicles owned and managed by a national government."

In 2020, the size of their managed assets reached USD 8.5 billion [4]. However this still comprises a minimal share in comparison to the managed assets of traditional financial institutions (banks, insurance companies, monetary funds, mutual funds). Nonetheless, in comparison with other alternative asset managers (private equity, hedge fund, and others) and together with the size of individual countries' foreign exchange reserves, we can discuss the increasing influence of SWFs. A number of authors deal with their continually increasing importance, addressing more than merely the growing size of their managed assets [3, 5, 6, 7, 8]. Moreover, Kotter and Lel [6] state, "their objectives and behaviour are not well understood." 
Each SWF has its own individual reason for being created; additionally, all funds have their own goal, which are mutually complementary and can change over time according to the specific needs of the given economy and the situation on the financial markets. Generally, the goal of an SWF is to: (i) protect a country's wealth and invest it properly for future use in case of an economic crisis; (ii) protect the national economy and state budget from risk due to export fluctuations; (iii) maintain the tenets of intergenerational equity after mineral resources have been depleted; and (iv) increase yields from foreign exchange reserves via investment [9].

In the past, SWFs were thought of as passive investors [5] with the goal of acquiring just a minority share in companies, without exerting fundamental influence on the decision making of the companies they co-owned. However, Dewender, Han and Malatesta [7], for example, have observed that SWFs are often active investors at present. Similarly, Bahoo, Alon, and Paltrinieri [8] point out that SWFs have become "true active investors whose goal is to increase their portfolios' returns rather than advance a political agenda." We can say that the main goal of "establishing SWFs [is] to preserve the state's autonomy and sovereignty through the power of finance. SWFs are also used as an investment vehicle for foreign investments" [10]. SWF strategy has been changing over the years, as put forward by Young [11]: "some SWFs now veer from traditional practices of safeguarding wealth to more experimental and high-risk strategies that claim to be able to diversify national economies from oil dependency, while also promising high returns." Bernstein, Lerner, and Schoar [12] state that SWFs can be understood as the world's primary investors into entrepreneurial and real estate resources. It is obvious that SWFs "tend to focus their real estate acquisition endeavors on cross-border investment," as documented by Liu [13], for example. According to Petrova et al. [14], what it is fundamental is that SWFs' investment strategies and goals distinctly influence the duration of the investment period, which depends on the purpose for which the fund was established. For example, a longer investment period is expected for savings SWFs than for stabilization or monetary funds.

The potential for certain SWFs to exert political influence as well as their lack of regulation and transparency are some of the greatest threats posed by SWFs. Nonetheless, as emphasized by Bahoo [8], the goal of increasing revenues from active investments currently prevails over exerting political influence. Reddy [15] states that "the government may view state-owned enterprises such as SWFs as a spring-boarding to create lasting geopolitical relations with other developed and emerging countries." He further remarks that "in the recent past, regulatory agencies and politicians of developed economies have raised numerous security issues, such as transparency and political influence on the fund management, fund returns and fund reporting of SWFs."

Their influence on the companies under their ownership also further proves the significance of SWFs. On one hand, a number of authors have investigated the suitability of SWFs in the context of government owned companies. Kubo and Phan [16] came to the conclusion that when a government already owns a company, the best option is ownership within a sovereign wealth fund. They also discovered a nonlinear relationship between government ownership and company performance." Next, they state that it greatly depends "on the impact of the type of state owner, and the role of controlling shareholders in corporate governance frameworks." Dewenter, Han, and Malatesta [7] have investigated how SWF investment influences company value. Their analysis "shows significant positive returns to announcements of SWF investments, resp. negative returns to announcements of SWF divestments." Reddy [15] investigates "SWFs' outward foreign direct investment patterns and acquisition deals in times of global financial market turbulence." He concludes that "SWFs' outward FDI choices are primarily determined by institutional transitions, market development and government legitimacy in the home country, thus to invest 
globally, earn higher economic returns, and secure resources. These choices are firmly motivated toward advanced financial markets, and real estate and infrastructure sectors."

\section{Data, Methodology and Empirical Results}

Data concerning SWFs are not published and publicly available within the standard database sources for financial or economic data. For this paper, we derived the data specific to SWFs from previously published academic papers and from reports by Preqin, the IE Foundation, the Sovereign Wealth Fund Institute, and TheCityUK. We used the International Monetary Fund for additional data.

In this paper, we started with the growing number of SWFs, the increasing size of their managed assets, the place of their establishment and operation, and their growing share in comparison with global foreign exchange reserves. We also dealt with SWF regulation and transparency as measured by the Linaburgh-Maduell Transparency Index. Not least, we have discussed SWF investment after 2008 during the financial crisis and during the coronavirus crisis.

Utilizing the above-mentioned analytic data, we have demonstrated SWFs' potential, including defining their essential pluses and minuses.

The first SWFs were established in the 1950s; however, they experienced a boom primarily in the $21^{\text {st }}$ century, when 30 SWFs were founded in each of the first two decades. On their website, the Sovereign Wealth Fund Institute [1] has a list of of SWFs arranged according to the size of their assets.

During the past ten years, the volume of SWFs' managed assets has more than doubled to equal USD 8.5 billion in the year 2020. In the following illustration, the structure of SWF resources can be seen as divided into oil and gas, non-commodity resources, and other commodities (unfortunately, only up until 2018, the year up to which data is available in this form).

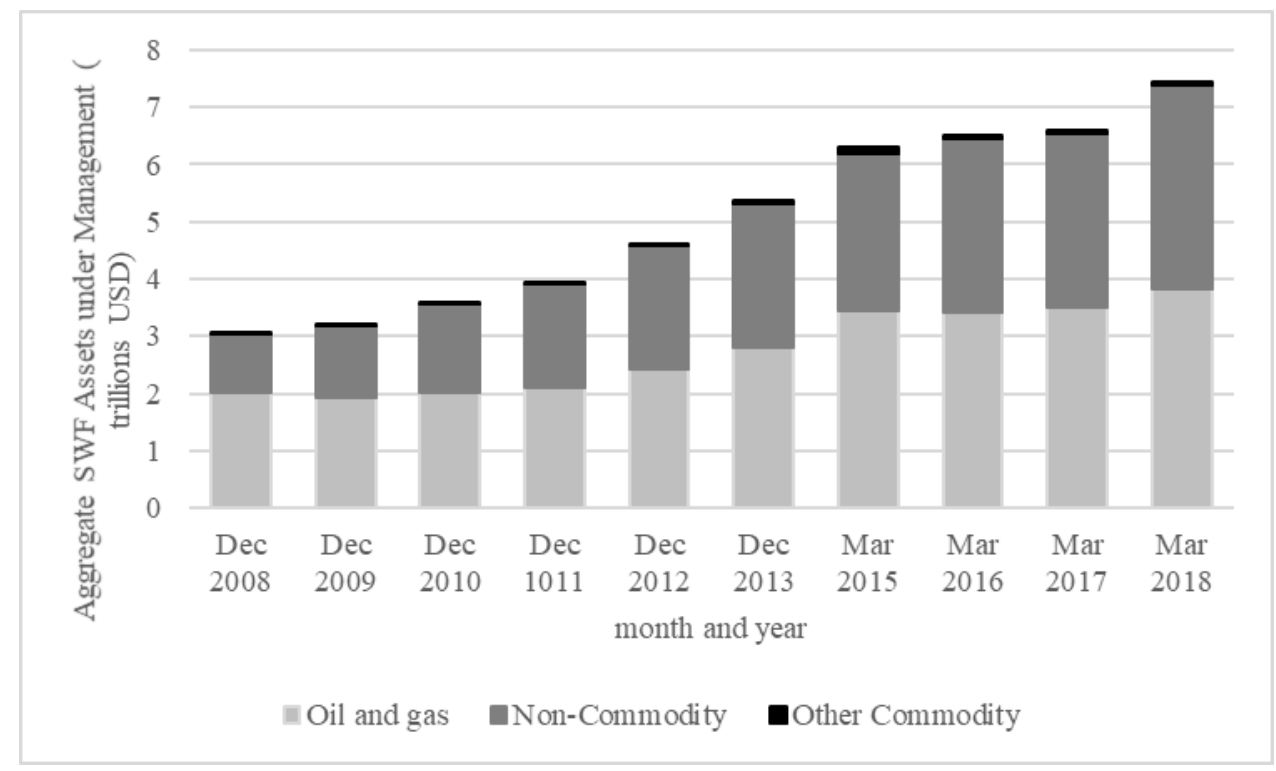

Fig. 1. The development of aggregate SWFs assets under Management

Source: [18] 
Up until 2015, assets grew at a yearly average of 9.4\%; after 2015, it was $6.2 \%$ [20]. Between 2007 and 2017, during the period for which we have comparable data, the value of managed SWF assets grew by $148 \%$ (see Fig. 2). The value of SWF managed assets grew more rapidly than global assets overall. This remarkable boom can be attributed to the constant increase in the number of sovereign wealth funds and their transactions, as well as the exceptional accumulation of assets by existing funds. Significance has been increasing for financial resources that tend to come out of a given country's revenues from exported goods and services in excess of import expenses as opposed to those derived from mining or oil/gas exports. When SWF investments are at this size, another essential source is revenues from active investments in the form of dividends, interest revenues, rent, etc.

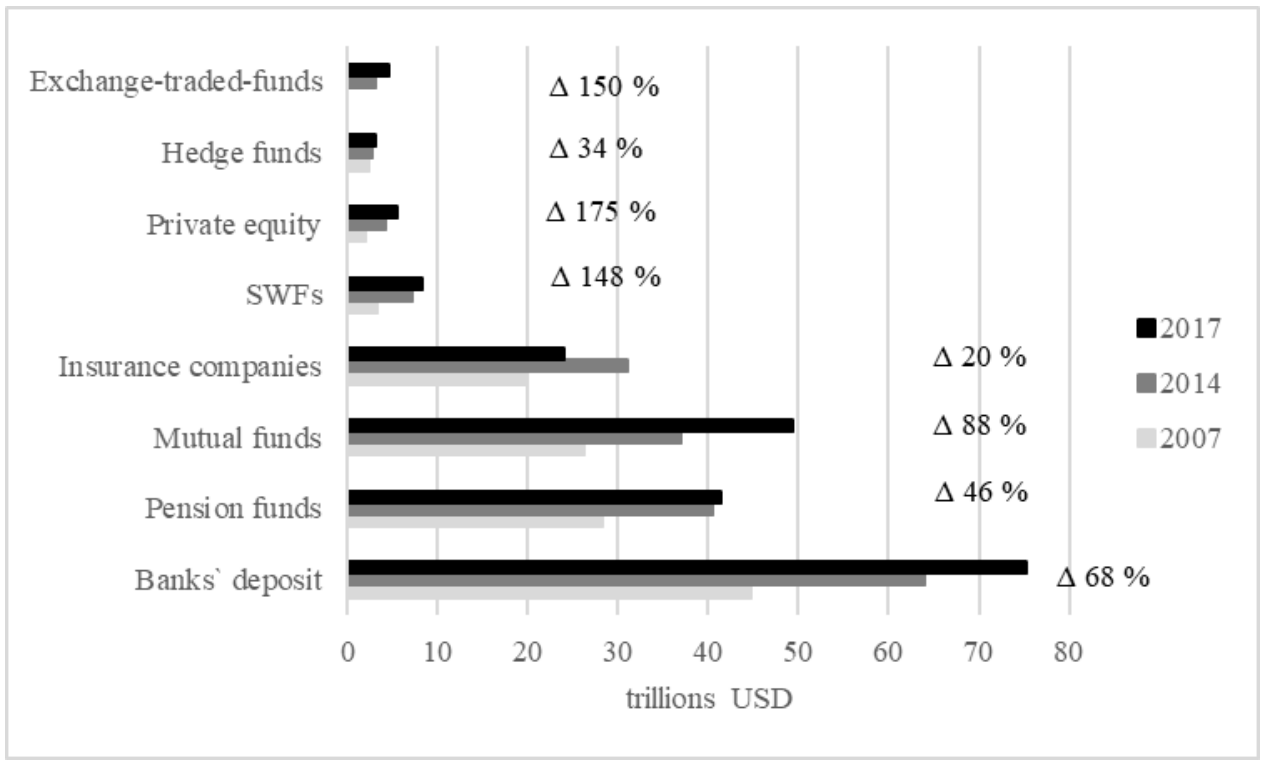

Fig. 2. The share of SWFs assets in the global investor portfolio

Source: [20]

In the following illustrations, the share of sovereign wealth funds on the international financial market is depicted in comparison to other investment intermediaries, and this clearly shows that these funds are not the dominant holders of capital in the world economy. Even if sovereign wealth funds increase in size, this would not be threatening enough to disrupt the financial markets. Their share of global financial assets has increased from $2.6 \%$ to $3.9 \%$. There is no apparent reason why their continuing development would be destabilizing or alarming. Conversely, it is necessary to see the sovereign wealth funds' assets as excess financial resources that could be utilized very effectively in the given country. 


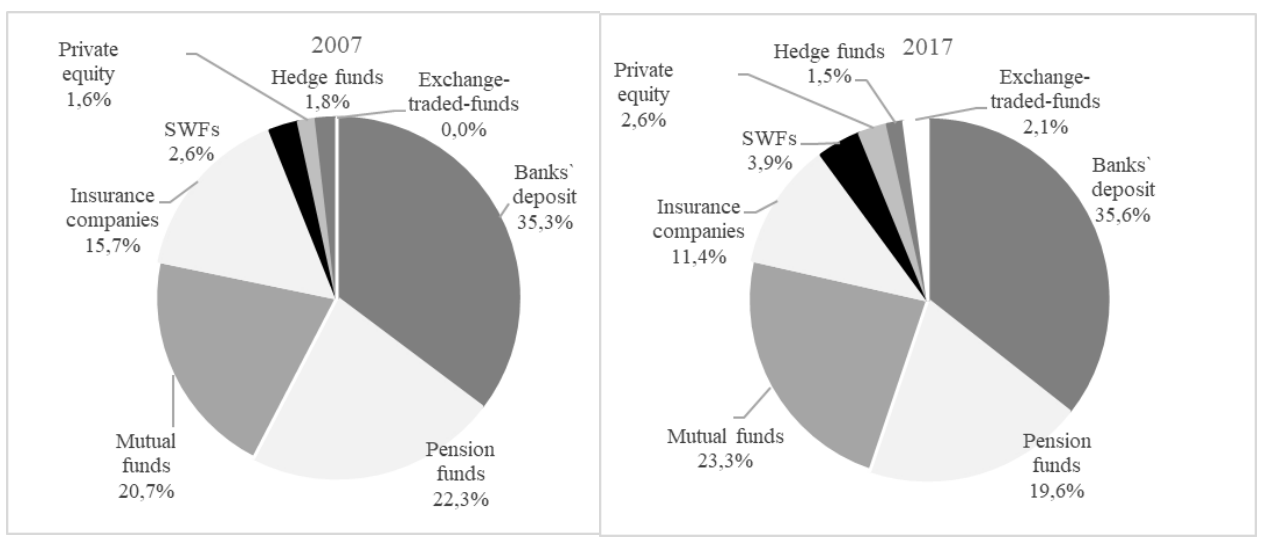

Fig. 3. The development of SWFs share of assets in the global investor portfolio Source: [20]

Most of these funds have been established in relatively unstable regions of East Asia and the Pacific (19 SWFs) and in the Middle East and North Africa (18 SWFs); there are 13 SWFs operating in Europe and Central Asia, 12 in North America, and 10 each in the Latin America/Caribbean region and in Sub-Saharan Africa [21]. The largest chunk of SWF investment is being poured into the USA and China (namely from China's domestic resources). Specifically, SWFs invested more than USD 80 billion in 2018 , with $82 \%$ of the value of these investments being made in five countries: the USA (30\%), China (24\%), the Netherlands (14\%), Australia (8\%), and France (6\%) [17].

Sovereign wealth funds were of distinct help to companies after 2008 during the period of the financial crisis. The following table summarizes the most important of these investments, with values over USD 2 billion. During the crisis years of 2008 and 2009, SWFs invested roughly USD 53 billion into endangered companies overall and thus played an important role in recovery from the crisis [22].

Table 1 The investment of SWFs in selected world banks and companies in 2007 a 2008

\begin{tabular}{|c|c|c|c|}
\hline Company & Investor & $\begin{array}{l}\text { Share } \\
\text { (in \%) }\end{array}$ & $\begin{array}{l}\text { Value of investment } \\
\text { (in mil. USD) }\end{array}$ \\
\hline UBS & $\begin{array}{l}\text { Government of Singapore Investment } \\
\text { Corp. }\end{array}$ & 9,8 & 9750 \\
\hline Citigroup & Abu Dhabi Investment Authority & 4,9 & 7500 \\
\hline Citigroup & $\begin{array}{l}\text { Government of Singapore Investment } \\
\text { Corp. }\end{array}$ & 3,7 & 6880 \\
\hline Morgan Stanley & China Investments Corporation & 9,9 & 5000 \\
\hline Merrill Lynch & Temasek Holdings & 9,4 & 4400 \\
\hline Sainsbury & $\begin{array}{l}\text { State Administration of Foreign } \\
\text { Exchange }\end{array}$ & 25,0 & 3700 \\
\hline Citigroup & Kuwait Investment Authority & 1,6 & 3000 \\
\hline $\begin{array}{l}\text { China Eastern } \\
\text { Airlines }\end{array}$ & Temasek Holdings & 8,3 & 2800 \\
\hline Blackstone Group & China Investments Corporation & 9,9 & 3000 \\
\hline Total & $\begin{array}{l}\text { State Administration of Foreign } \\
\text { Exchange }\end{array}$ & 2,6 & 2800 \\
\hline Barclays PLC & Temasek Holdings & 1,8 & 2005 \\
\hline
\end{tabular}

Source: [22] 
In conjunction with the COVID-19 pandemic, a number of countries have inclined towards drawing on their sovereign wealth funds' savings to help lessen the impact of the global drop in the price of oil. The International Forum of Sovereign Wealth Funds also became involved and is overseeing how these long-term asset owners are reacting to the crisis. For example, Russia's sovereign wealth fund has participated in mass-producing medicine that is effective in treating the coronavirus. Temasek Holdings is focusing on financial aid to countries affected by the coronavirus. Together with prominent financial institutions, China Investment Corp. and Singapore's GIC discussed an investment strategy and agreed to expand cooperation so that they could help revive the global economy.

A fundamental indicator of SWFs' increasing importance is the comparison of their managed assets' values to the size of global foreign exchange reserves. In 2008, the value of SWF assets was $46 \%$ of global foreign exchange reserves (se Table 2). In 2020, it was already $74 \%$. Global foreign exchange reserves grew by $55 \%$ during this period, with SWF assets growing by $150 \%$. Using the example of the largest SWF in the world, the Norwegian Government Pension Fund Global, it can be said that the value of certain countries' SWF assets is greater than that of their foreign exchange reserves - by nearly 15 times in Norway's case.

Table 2 The ratio of SWFs assets under management to global foreign exchange reserves

\begin{tabular}{|l|r|r|r|}
\hline Year & Exchange reserves (trillion USD) & Assets SWFs (trillion USD) & Assets/exch.reserves \\
\hline 2008 & 7,34 & 3,4 & $46 \%$ \\
\hline 2011 & 10,21 & 4,7 & $46 \%$ \\
\hline 2013 & 11,70 & 6,0 & $51 \%$ \\
\hline 2016 & 10,73 & 6,8 & $63 \%$ \\
\hline 2017 & 11,46 & 7,5 & $65 \%$ \\
\hline 2018 & 11,43 & 7,7 & $67 \%$ \\
\hline 2020 & 11,44 & 8,5 & $74 \%$ \\
\hline
\end{tabular}

Source: $[4,23]$

There is a lot of criticism levied towards SWFs because of their low levels of transparency and regulation. Legal regulation of sovereign wealth funds happens on account of concerns about possible political influence resulting from their investments into companies and the enormous amount of capital they have available. Furthermore, SWFs can access internal company information, and their structure and goals are often nontransparent. Moreover, they add to market volatility. Their dealings can cause extreme market fluctuation, because they own substantial percentages of the companies in which they have invested. SWFs are not regulated by any supranational body. Sovereign wealth funds are governed by the national regulations that each country decides to use for their SWFs.

Therefore, in order to formalize, coordinate, and simplify relationships, the International Monetary and Financial Committee created an international working group composed of fund representatives. At their 2008 session, they approved a document describing the basic rules of operation: The Santiago Principles consists of 24 generally accepted principles and practices voluntarily endorsed by International Forum of Sovereign Wealth Fund members. The Santiago Principles promote transparency, good governance, accountability, and prudent investment practices whilst encouraging a more open dialogue and deeper understanding of SWF activities. 
The economic significance of SWFs will always reflect their credibility, which distinctly relates to their level of transparency. Of the ten largest funds, three are from China and three are from Arabic nations, which can represent certain security and political risks. This matches the transparency index values for these funds, which are not very high and hover between 4 and 7, of a maximum 10 points. In general, SWFs from less developed countries often even earn index values between 1 and 4. The Sovereign Wealth Fund Institute [1] goes into more detail on evaluating transparency.

\section{Discussion}

The above data clearly demonstrates the marked growth of SWF assets. Likewise, their influence is increasing via the investments they have made. Nonetheless, in comparison with the managed resources of other financial institutions, their importance is still relatively small. As stated by Bernstein, Lerner, and Schoar [12], even though they occupy a minor position among the ranks of important companies, they do have a certain significant proportion of influence. This is the main reason why SWFs are discussed so much in academic and political spheres.

If a country has excess financial resources and would like to be active in the financial markets, we believe that as a government investor, founding an SWF is the best option. It is definitely a better option than if such expansive resources were managed by a minister of finance or government owned enterprises. Therefore, we agree with Kubo and Phan [16], who came to the conclusion that if a country owns companies, the best choice is for these to take the form of a sovereign wealth fund. Naturally, this is conditional on having the SWF's processes properly established; these should not be influenced by politicians' actual positions. The fund should be managed by investment specialists and should utilize a longterm investment standpoint. At the same time, this way of managing government assets appears to be more advantageous over the long term than maintaining foreign exchange reserves. Generally, these tend to be invested very conservatively with the goal of maintaining their value. Conversely, SWF assets are invested with the goal of long-term yields. Therefore, currently, most assets are invested in stock as well as into real estate.

Because sovereign wealth funds act as shareholders, it is necessary to judge their importance on the financial markets from at least two perspectives. They can operate as an excellent vehicle for financial resources providing an impulse to further develop companies, or they can represent a potential threat for individual developed countries in the form of a certain loss of control over important companies. We see the fundamental benefit of establishing an SWF to be creating financial resources for future generations rather than having these be spent by the politicians of the time. As to the countries in which SWFs invest, the invisible benefit for them is then increasing their access to financial capital. Besides the influx of capital, SWFs can also improve the effectiveness of price setting. Funds have also contributed to a number of analyses conducted on stock and bond markets. In times of crisis due to economic downturns, SWFs tend to behave as long-term investors. This means that they support companies in financial trouble - those, however, in which they see future potential growth. Therefore, we agree with Reddy [15], who sees SWF investment and acquisitions in times of turbulence on the global financial market as a model for direct foreign investment. At the same time, SWFs' investment strategy is changing as they transform from passive investors to active ones, which has been confirmed by Dewenter, Han and Malatesta [7], among others. Equally, SWFs are currently investing in high-risk assets, as stated by Young [11]. SWFs can simultaneously help stipulated countries with transferring financial resources and financing development activities. 
The greatest threat is seen in concerns that states that own SWFs would exert political influence. Concerning this scenario, we lean towards Bahoo's [8] conclusion that the goal of SWFs "is to increase their portfolios' returns rather than advance a political agenda." The varying levels of SWF transparency relate to this issue, which is primarily valid for less transparent funds, established as a rule in Arab nations, China, and less developed countries. However, there are no documented cases of abuse of power by any SWF. Existing national legal regulations are sufficient for resolving potential safety threats.

Concerning regulating SWFs, we oppose greater SWF controls, because this always leads to lowering effectiveness and decreasing investment levels in the given country. Currently, the basic parameters for transparency, i.e., concerning the exertion of political influence on fund management by the proprietary states, have been established. We consider this sufficient, primarily where trusted nations are concerned. As Reddy [15] states, SWFs can be considered a stepping stone for creating permanent geopolitical relationships with other developed and developing countries.

As important investors into long-term capital, sovereign wealth funds play an important role in stabilizing both national economies as well as the global financial system. For regional economies fighting the coronavirus pandemic and the crippling impact of lower oil prices, sovereign wealth funds should be used to help revive the global economy. Countries with sovereign wealth funds entered the crisis with distinct fiscal leeway, thanks to SWFs' large savings or low levels of debt. It has been proposed that fiscal responsibility during a period of expansion include the possibility of drawing on savings or providing loans during a crisis period, such as now [24].

The following pluses and minus of SWFs can be summarized using the above. We can consider the positive aspects to be that SWFs (i) stabilize the financial markets in the face of financial and economic crises, (ii) increase the availability of capital, (iii) more evenly divide wealth between generations, (iv) finance development projects, and (v) diversify a country's revenues. Some negative aspects include (i) low transparency (most SWFs, but not all), (ii) the possibility of promoting political goals, (iii) the possibility of higher corruption in the event of political influence on fund management, and (iv) destabilizing the financial market contingent upon extensive selling.

The future of sovereign wealth funds depends on the interplay of a number of factors, for example (i) development on the commodities markets, primarily the price of oil, (ii) political and economic development, (iii) demographic trends in the home countries, (iv) the extent of regulation, and (v) the degree of return on their investment.

\section{Conclusion}

Sovereign wealth funds are considered investment tools established to manage holdings of national wealth for future generations. In the present day, SWFs are among the most important institutional investors on the global financial markets and similar to other financial institutions, they manage an enormous amount of capital, whose volume is constantly increasing. The fact that they are owned, managed, and controlled by independent nations and that they have limited need for liquidity, a long-term intergenerational timeline, and relatively high risk tolerance makes them different from other financial institutions. Sovereign wealth funds invest primarily into the advanced economies of the USA, Europe, and Japan, because their financial markets are deep and well-developed. The presence of sovereign wealth funds on developing markets also indicates a certain rising trend.

Distrust of SWFs has decreased, and they are considered legitimate, influential, and significant participants on the global financial markets, and they can be described as viable business models for investing the reserves of a given country. 
SWF expansion is an important aspect of international investment, and despite certain problems of regulation and transparency, these funds will mostly likely become even more important as players on the financial markets and forces shaping the global economy. They will continue to be important custodians of national assets with multigenerational agency, and their activities will influence both their fields of engagement as well as the way companies are run. Due to their focus on long-term investment, they will contribute to greater stability on the financial markets.

This paper has been created with financial support from the Czech Science Foundation as part of project GACR No. GA 18-05244S, Innovative approaches to credit risk management and project of University of Pardubice No. SGS_2020_014, Advanced analysis of economic and social aspects of public policies and their dynamics in the context of efficiency and sustainability.

\section{References}

1. Sovereign Wealth Fund Institute. (2020, September 10). World's Most Popular and Trusted Source on Institutional Investors and Global Capital. Retrieved from: https://www.swfinstitute.org

2. International Monetary Fund. (2008, February 29). Sovereign Wealth Funds - A Work Agenda. Retrieved from: https://www.imf.org/en/Publications/PolicyPapers/Issues/2016/12/31/Sovereign-Wealth-Funds-A-Work-Agenda-PP4234

3. Connelly, B. L., Hoskisson, R. E., Tihanyi, L., Certo, S. T. (2010). Ownership as a Form of Corporate Governance. Journal of Management Studies, 47(8), 1561-1589.

4. Sovereign Wealth Fund Institute. (2019, June 12). Sovereign Wealth Fund Assets Under Management. Retrived from: https://www.swfinstitute.org/news/76389/chart-ofthe-day-sovereign-wealth-fund-assets-under-management

5. Aguilera, R. V., Jackson, G. (2010). Comparative and International Corporate. The Academy of Management Annals, 4(1), 485-556.

6. Kotter, J., Lel, U. (2011). Friends or foes? Target selection decisions of sovereign wealth funds and their consequences. Journal of Financial Economics, 101(2011), 360-381.

7. Dewenter, K. L., Han, X., Malatesta, P. H. (2010). Firm values and sovereign wealth fund investments. Journal of Financial Economics, 98(2010), 256-278.

8. Bahoo, S., Alon, I., Paltrinieri, A. (2020). Sovereign wealth funds: Past, present and future. International Review of Financial Analysis, 67(2020), 1-17.

9. Khalil, S. (2020, September 10). Sovereign funds to manage the wealth of countries. Who manages the wealth of Iraq?! Retrieved from: https://rawabetcenter.com/en/?p=7400

10. Murtinu, S., Scalera, V. G. (2016). Sovereign Wealth Funds' Internationalization Strategies: The Use of Investment Vehicles. Journal of International Management, 22(2016), 249-264.

11. Young, K. E. (2020). Sovereign risk: Gulf sovereign wealth funds as engines of growth and political resource. British Journal of Middle Eastern Studies, 47(1), 96-116.

12. Bernstein, S., Lerner J., Schoar, A. (2013). The Investment Strategies of Sovereign Wealth Funds. Journal of Economic Perspectives, 27(2), 219-238

13. Liu, P., Mauck, N., Price, S. M. (2019). Are Government Owned Investment Funds Created Equal? Evidence from Sovereign Wealth Fund Real Estate Acquisitions. The Journal of Real Estate Finance and Economics, 61(2020), 698-729. 
14. Petrova, I., Pihlman, J., Kunzel, P. J., Lu, Y. (2011). Investment objectives of sovereign wealth funds-a shifting paradigm. IMF Working Papers, 11(19), 1-16.

15. Reddy, K. S. (2019). Pot the ball? Sovereign wealth funds' outward FDI in times of global financial market turbulence: A yield institutions-based view. Central Bank Review, 19(2019), 129-139.

16. Kubo, K., Phan, H. V. (2019). State ownership, sovereign wealth fund and their effects on firm performance: Empirical evidence from Vietnam. Pacific-Basin Finance Journal, 58(2019), 1-21.

17. Capapé, J. (2020, September 10). Sovereign wealth funds 2018. Retrieved from: https://docs.ie.edu/cgc/SWF-CGC-2018.pdf

18. Preqin. (2018, August 31). Preqin special report: sovereign wealth funds. Retrieved from: https://docs.preqin.com/reports/Preqin-Special-Report-Sovereign-Wealth-FundsAugust-2018.pdf

19. PWC. (2020, September 9). Sovereign Investors 2020: A growing force. Retrieved from: https://www.pwc.com/ee/et/publications/pub/sovereign-investors-2020.pdf.

20. TheCityUK. (2019, September 7). Global Financial Markets: Regional Trends. Retrieved from: http://www.thecityuk.com/media/191881/global $\% 20$ fin $\%$ 20mkts\%20regional\%20trends\%202010.

21. Hilaire, A. (2019, March 27) Sovereign Wealth Funds: Practical Experience and Lessons from Trinidad and Tobago. Retrieved from https://www.centralbank.org.tt/sites/default/files/presentations/swfs-trinidad-and-tobago-experiencemarch-2019.pdf.

22. Kern, S. (2009, July 31). Sovereign wealth funds -state investments during the financial crisis. Retrieved from: www.dbresearch.com/PROD/DBR_INTERNET_ ENPROD/PROD0000000000244283.pdf.

23. International Monetary Fund. (2020, September 10). World Currency Composition of Official Foreign Exchange Reserves. Retrieved from: https://data.imf.org/regular.aspx?key=41175.

24. Tesnerová, K. (2020, May 30). Význam suverénních fondů na celosvětovém finančním trhu. Retrieved from: https://dk.upce.cz//handle/10195/75575. 